\title{
Juxtaposing a cultural reading of landscape with institutional boundaries: the case of the Masebe Nature Reserve, South Africa
}

\author{
Chris Boonzaaier and Harry Wels
}

\begin{abstract}
The article explores theoretically the juxtaposition of local stories about landscape with institutional arrangements and exclusionary practices around a conservation area in South Africa. The Masebe Nature Reserve is used as a case study. The article argues that the institutional arrangements in which the nature reserve is currently positioned are too static, and consequently exclusionary, in their demarcation of boundaries. This stifles local communities' sense of belonging to these landscapes. Hence, they strongly resent and feel alienated by the nature reserve. Their opposition and alienation often manifests in poaching. The empirical material is based on how local people living adjacent to the Masebe Nature Reserve have historically named and interpreted the area's impressive sandstone mountains, in the process creating a sense of belonging. Juxtaposing this mostly tranquil cultural reading of the landscape to the institutional practices of boundary demarcation gives the analysis an immediate critical edge regarding issues of social justice
\end{abstract}

\section{Introduction: juxtaposing landscapes and institutional boundaries}

The concept of landscape has shifted from its common denotation of 'scenery' and is increasingly becoming a construct that connotes contested spaces of power and politics and has come to be framed and evaluated in terms of social justice (Olwig \& Mitchell, 2009). This also applies to South Africa, whose landscapes are described by Jeremy Cronin, a poet, activist and South Africa's Deputy Minister of Transport from 2009, as 'a countrywide grid of spatial controls ... with endless spaces within other spaces' (Cronin, quoted in Barnard, 2007, p. 6). These spaces have become a crucial locus of resistance' (Cronin, in Barnard, 2007, p. 7).

This resistance in South Africa is often articulated in stories (Scheub, 2010) and the recollection of memories linked to particular landscapes (Schama, 1995). Every landscape 'is full of memory, either by deposited material remainders and structures, or by stories linked to place and former times' and the 'surroundings are loaded with stories from the past, sometimes affirmed by official names of terrains' (Lengkeek, 2008, pp. 42-43). In the case of the Masebe Nature Reserve in the Limpopo Province of South Africa (see Figure 1), the indigenous (and unofficial) names of the mountains reflect how the people themselves 'read' the landscape, and appropriate it on the basis of memories, and narratives in which these memories are embedded. 


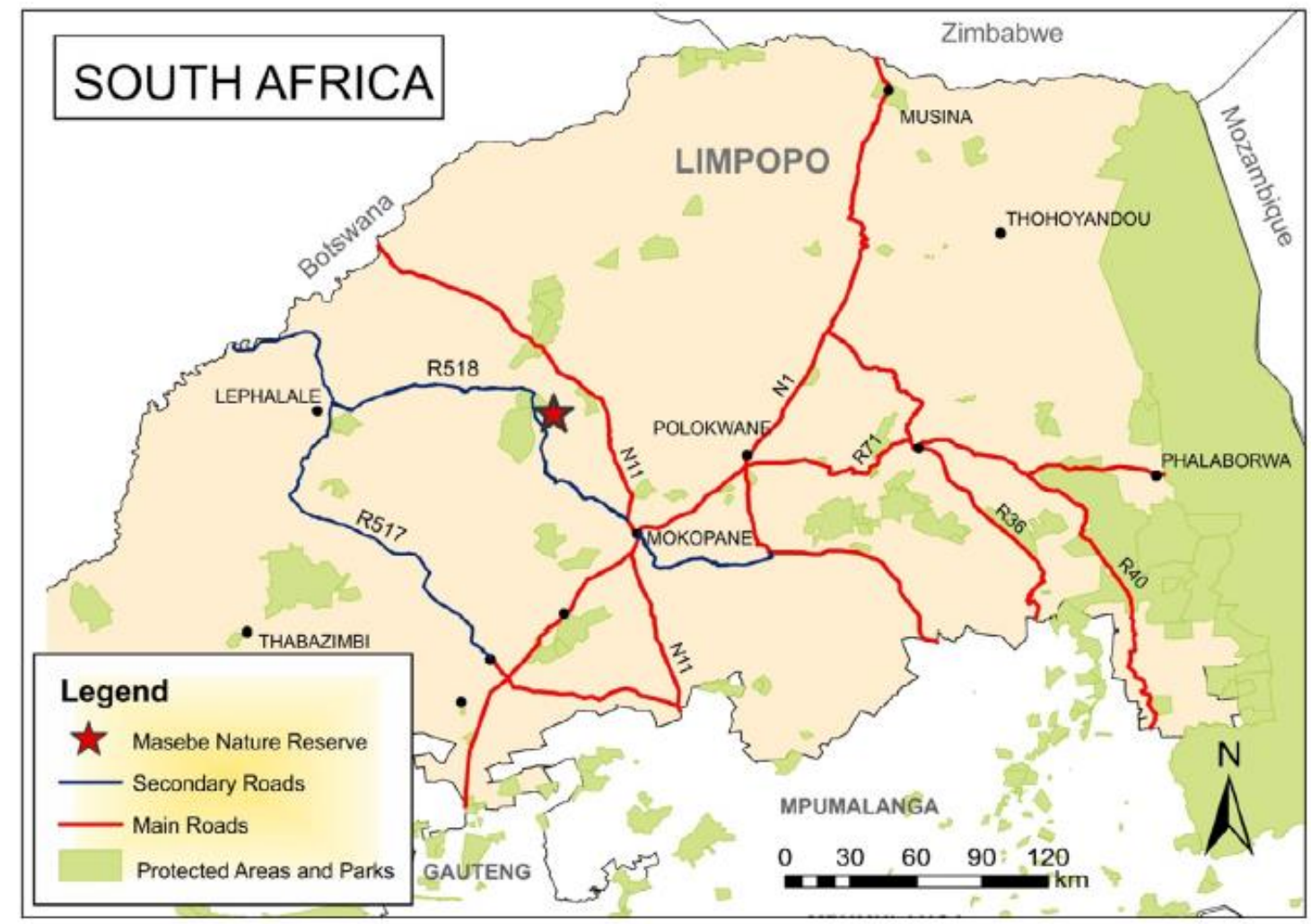

Figure 1. Location of Masebe Nature Reserve (DRDLR, 2011a; University of Pretoria and Department of Environmental Affairs, 2002).

In much conservation across the world, institutional arrangements and exclusionary practices are imposed by conservation authorities in the form of fences (Wels, 2000) which often cut right through a cultural reading of a landscape-institutional boundaries hardly, if ever, take cognisance of cultural readings of landscapes; landscapes' own '[v]oices from the rocks' (Ranger, 1999) enjoy less recognition in globalised discourses than western-dominated institutional boundaries (Drori, Meyer, \& Hwang, 2006). In the case of the Masebe Nature Reserve, exclusionary practices are reflected in the fencing of the area, resulting in general discontent among the residents in the seven surrounding villages. The most important effect of the fencing of the Masebe Nature Reserve has been that the people have been deprived of some of their grazing. Moreover, the fence excludes the women from the area where they used to collect thatch and firewood. Traditional practitioners also no longer have unimpeded access to a variety of medicinal plants found in the Reserve. The fence cuts off direct access to ancestral graves, which are important places of veneration and sacrifice for these communities. Since the Reserve has been fenced, there has been a high incidence of poaching in the Reserve (Boonzaaier, 2010, pp. 59-62). It has been suggested that 'poaching' can be read as 'communicating discontent', especially when wire meant to keep wildlife in and potential poachers out is used in this' poaching'(Wels, 2003, pp. 221-227).

It is not always easy to recognise the political implications of local surrounding communities' marginalisation from the ways in which they 'read' and speak about the landscape, or even to see what exactly characterises their reactions as 'resistance'. The stories and anecdotes that were reconstructed during our fieldwork (see below) may seem apolitical, even nostalgic, rather than 
revolutionary or critical, or expressions of resistance. It is in the act of juxtaposing this discourse with the institutional boundaries in which the Masebe Nature Reserve is framed and captured today that the critical edge of social injustices become visible and evident.

\section{The Masebe Nature Reserve}

The Masebe Nature Reserve is situated about $95 \mathrm{~km}$ from Mokopane, $24 \mathrm{~km}$ from Marken and 130 $\mathrm{km}$ from Polokwane (see Figure 1, inset map). It comprises an area of 4451 hectares in the northern part of the Langa Ndebele chiefdom, ruled by Chief Phillip Bakenberg. In the late nineteenth century, the government of the zuid-Afrikaansche Republiek under President Kruger divided the Langa chiefdom into a northern and a southern part after Chief Masebe III committed suicide on 4 May 1890. The southern part, the site of the old capital of Mapela at Fothane Hill, was allotted to Masebe's son Hans Langa and became known as bagaMapela ('those of Mapela's place'); the northern part was allotted to Masebe's son Bakenberg Langa (De Beer, 1986; Jackson, 1982, pp. 3940).

The Masebe Nature Reserve is part of the Waterberg mountain range. It features impressive sandstone formations. The flora includes a wide variety of indigenous trees, and its fauna includes various kinds of antelope, such as kudu, eland, klipspringer, bushbuck and impala. There are also some giraffes in the Reserve. The human influence in the Masebe Nature Reserve is reflected by the fact that, except for leopards (which are rarely seen), there are no predators in the Reserve. Other members of the 'Big Five' (elephant, buffalo, rhinoceros and lion) and hippopotami are also not found in the Reserve.

Part of the human legacy in the landscape, in a historic-cultural sense, is found in a number of rock paintings on sandstone under overhanging cliffs in the mountains. A site associated with military history is Magagamatala, one of the mountains in the range in the Reserve. At this site, in 1858, the Langa Ndebele were attacked and defeated by a Boer punitive expedition led by Commandant- General Stephanus Schoeman and his commandant, Paul Kruger, who later became president of the zuid-Afrikaansche Republiek; the expedition avenged the massacre of a group of Voortrekkers led by Hermanus Potgieter in 1854 (Jackson, 1982, pp.13-18).

Another mountain of particular historical and archaeological significance is Thabana ya kgoši ('Little mountain of the king'), which is closely associated with the historical events at Magagamatala. When the Langa retreated to Magagamatala in 1854, anticipating a punitive raid by the Boers, the Langa chief, Mankopane, as was customary, did not reside with his people. He lived at the foot of Thabana ya kgoši until 1858. This precaution enabled Mankopane to escape when the Langa were defeated at Magagamatala. Today, the remains of terraces at the foot of Thabana ya kgoši provide archaeological evidence of the Langa chief's stay at this mountain.

The Masebe Nature Reserve was established in accordance with a resolution of 17 February 1984, when the Langa Ndebele chief, his private councillors (48 village headmen who constituted the Bakenberg Tribal Authority, now called the Bakenberg Traditional Council), and 500 members of the Langa tribal community agreed to develop 4451 hectares of trust land as a nature reserve. Until then, the land had been used for communal grazing for the stock owners of the seven 
Langa villages, Moshuka, GaMathekga, Dipêrê, GaMonare, Rapadi, Senita and Skrikfontein/Magagamatala (seeFigure1).

Today, the Masebe Nature Reserve forms part of the greater Waterberg Biosphere Reserve, which has been awarded international status and was registered with UNESCO in March 2001. The main reason for including the Langa Ndebele land in the Waterberg Biosphere Reserve was to enable the tribal community to become a stakeholder in the development and conservation of the Waterberg Biosphere. As part of the Langa Ndebele chiefdom, the Masebe Nature Reserve can play a role in promoting the overall objective of the Waterberg Biosphere: to integrate conservation of natural resources in the Waterberg with economic development of local villages. The intention is to achieve this objective by creating more opportunities for decision-making and planning by means of institutional development and community empowerment (Boonzaaier \& Wilson, 2011, p. 168; see also Eckert, De Beer, \& Vorster, 2001).

The main empirical body of this article is an exploration of a cultural reading of the landscape of the Masebe Nature Reserve, based on how local residents from the seven surrounding villages themselves name and interpret the various meanings of the landscape, as advocated by Cosgrove (1984), Cosgrove and Daniels (1988), De Beer (1999), Schama (1995) and Whiston Spirn (1998). This article follows the principles outlined by Ranger (1997, p. 59), who suggests discovering how local people 'submit [a landscape] to their imagination; (...) appropriate it to their culture; [and] annex it to their history'. The article is exploratory in that some features of the landscape were identified by local residents only by means of a brief anecdote, or on the basis of a particular incident, whereas other aspects of the landscape gave rise to far more elaborate (his)stories and interpretations.

In the empirical research process, 15 elders were interviewed, sometimes individually, because not all the interviewees were conversant with the meanings and stories of all the mountains in the Reserve. Langa people who no longer resided in the community area, but whom other interviewees pointed out as knowledgeable on the subject, were traced and interviewed. A particular effort was made to verify the information at the end of the research period by conducting a group discussion with those elders (five in total) who had proved to be the most knowledgeable on the topic.

\section{Reading the cultural landscape of the mountains of the Masebe Nature Reserve}

The Masebe Nature Reserve is a good example of the tendency for institutional boundaries to cut right through the cultural reading of the landscape, as described above. When the Reserve was fenced in the mid-1980s, six of the mountains we discuss-Lebata, Thabana ya Ntebele, Setlhakwame, Bojelaphiri, Thabantsho (1\&2) and Diphikana (see Figure 2)-were not included in the Reserve. It appears that in the negotiations between the government and representatives of the Langa tribal community to establish the Reserve, no consideration was given to the cultural landscape in which the Reserve is situated and the values, meanings and practices associated with the area. It may be fairly safely assumed that the government representatives in the negotiations, as relative outsiders, were ignorant of the cultural values attached to the particular landscape. On the other hand, it seems that the Chief, his councillors and other tribal representatives did not realise the possible implications of fencing and may have been carried away by the economic benefits that they envisaged the proposed Reserve might generate, such as income received from hunting, 
visitor entrance fees and accommodation, and the provision of venison to community members from game hunted on the Reserve (Boonzaaier, 2010).

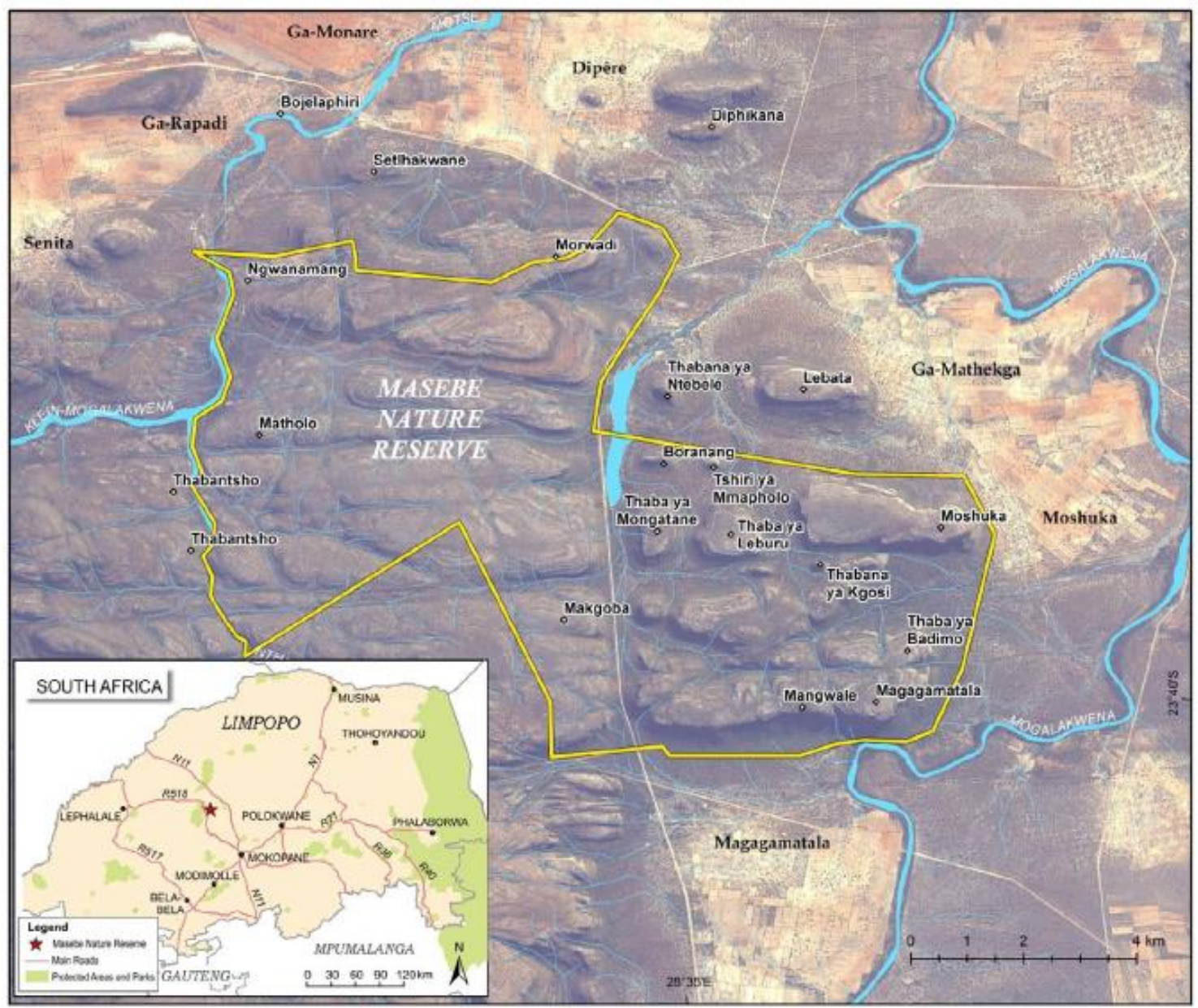

Figure 2. The Masebe Nature Reserve, seven surrounding villages and mountains in the cultural landscape mentioned in the text. (DRDLR, 2011b; SANSA, 2012). 


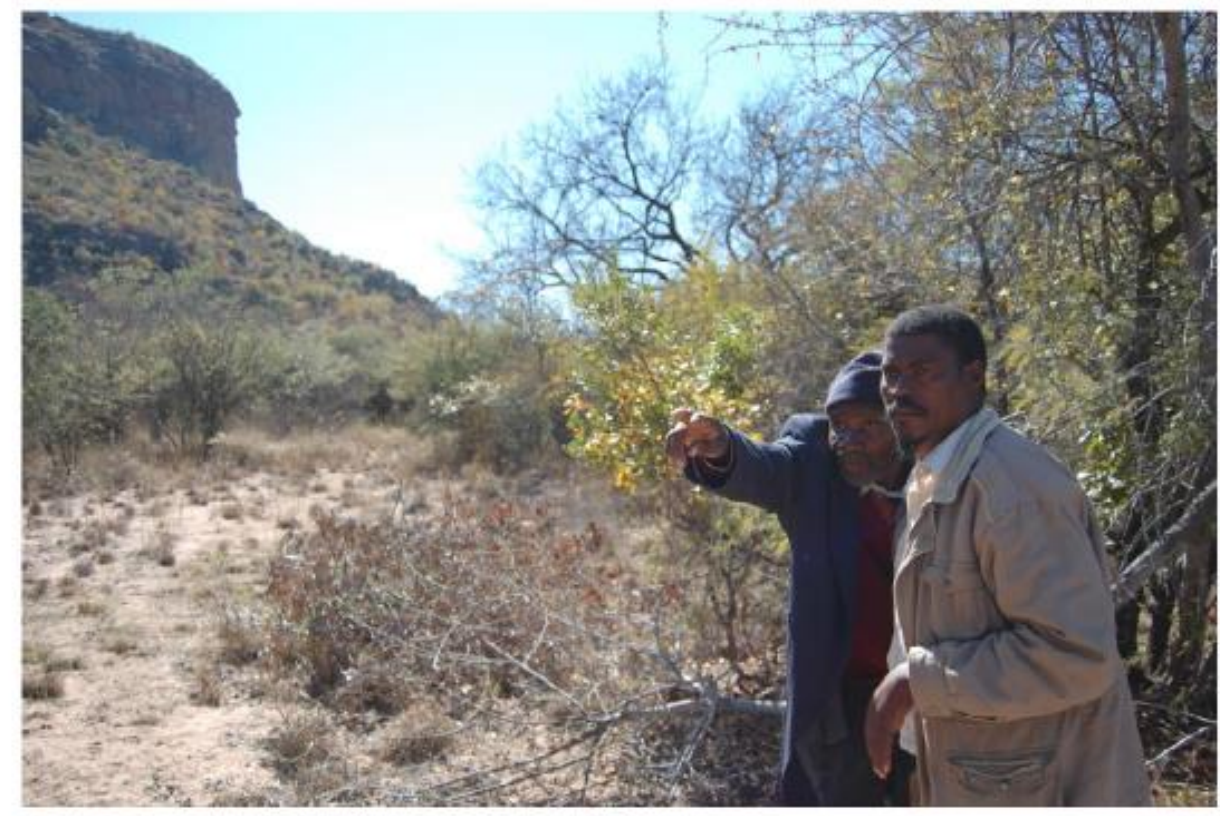

Figure 3. Ntona Daniël Malope pointing out a feature in the landscape to ntona Mathekga. Photographed by Boonzaaier 2013.

Ignorance of local cultural values and meanings attached to a landscape is, as we indicated above, common worldwide. For instance, referring to the Nepalese Himalayas, Lhakpa (2006, cited by Taylor, 2012, p. 36) comments on the establishment of protected areas 'without proper recognition of the symbiotic relationship between local communities and environmental conservation'.

However, from the interviews (in other words, 'read through the eyes of the people'), it became clear that the residents of the seven villages surrounding the reserve (see Figure 1) regard the mountains outside the Reserve as an integral part of the cultural landscape of the Masebe Nature Reserve, showing that recent institutional boundary-making does not necessarily follow the reading of the cultural landscape by the local residents. In fact, previous research has revealed that there was serious discontent about the fencing of the Reserve, because the fences separate local residents from their ancestors and prevent the people from using the natural resources in the Reserve area as they did before (Boonzaaier, 2010). Hence, these mountains were included in the discussion in the article, as they are considered an integral part of the cultural landscape (see Figure 2).

An analysis of the local meaning and names of the mountains makes it possible to categorise them according to particular features, historical events, cultural practices or the abode of people or even animals(Figure 3).

\section{Mountainsnamedforparticularnaturalfeaturesorassociations}

Some mountains in the landscape where the Masebe Nature Reserve is situated are named for their particular natural features rather than for their cultural significance, for example Moshuka and Lebata (see below). Mountains such as Tshiri ya Mmapholo, Thabantsho and Diphikana (outside the Reserve) (see Figure 1) are significant only for their physical appearance, as reflected in their names. 
Other mountains, such as Boranang, Matholo and Bojelaphiri (see Figure 1), are associated with specific animals because of the presence of these animals at those places. As we explained in more detail later (see Mountains where particular people lived), Langa community members have no human- centred view of place, but their concept of place includes non-human beings (Boonzaaier, 2010, p. 61; see also Harrison \& Rose, 2010, p. 258). Individual mountains are discussed below.

\section{Moshuka}

This mountain has religious significance, but the Langa people chose to name it for its appearance. If one looks at Moshuka from the east, one sees a small pinnacle at the southern side of the mountain that resembles a moshuka-the penis sheath of a bull, upside down. The whole mountain is named after this little mountain or pinnacle. Moshuka has a flat top, and in the rainy season, there is usually water on top of this mountain. This is regarded as the dwelling place of Mamogašwa/Twanado, the mythical water snake. A number of taboos are associated with this place. For instance, only rainmakers may approach this place and then only if they do so in the correct way. If ordinary people were to approach the place, they are liable to be caught by Mamogašwa, who will draw them into the water. Boonzaaier (2010, p. 61) reports tales of how 'people have disappeared because they apparently unknowingly entered Mamogašwa's dwelling place'.

Traditional practitioners used to ascend this mountain for rain-making purposes. Even adherents of the Apostolic and zionist Christian Church congregations have gone up this mountain go phaša badimo (to bring a sacrifice to the ancestors). However, they were never allowed to baptise people at the dwelling places of Mamogašwa.

\section{Tshiriya Mmapholo - 'hair of Mmapholo'}

A man called Mmapholo used to shave his hair at the sides of his head, leaving the hair on top to grow without cutting it at all-in a sense making a spectacle of himself. This mountain was named after old Mmapholo for the obvious reason that it has bare cliffs, with vegetation only on the top, which reminded the people of the way in which Mmapholo used to shave his head.

\section{Thabantsho - 'black mountain'}

As this mountain's name suggests, it looks slightly darker than the other mountains. The mountain is situated at the far western side of the Reserve, on the opposite side of the Ntubu River. Only the foot of this mountain lies within the Reserve fence.

\section{Diphikana}

The name is derived from the word diphika (cloaks). The name Diphikana refers to two mountains to the northeast of Morwadi (see below), outside the Reserve. These mountains form a natural enclosure (see Figure 1, top centre). Like a cloak covering or protecting a person, the enclosure formed by these two mountains 'covered'community members'cattle, hence the reciprocal form of diphika, namely diphikana. 


\section{Boranang - 'place of worms'}

The name refers to worms that appear there at the end of winter. They were particularly abundant on this mountain and were regarded as a pest, since they destroyed all the wild pear trees (mekgoba) (Botanical name: dombeya rotundifolia) that grew on the mountain.

\section{Matholo - 'Kudu mountain'}

Plenty of kudu were usually found at this mountain.

\section{Bojelaphiri - 'place where the hyenas eat'}

Hunters often found hyenas at this place. Initiation schools wereheld here until 1989.

\section{Mountains associated with historical events}

Five mountains are associated strongly with the Langa community's history and aid the collective memory of past events. Two of these mountains (Setlhakwame and Morwadi) (see Figure 1) are situated outside the Reserve, another indication that landscape, especially insofar as historical events are attached to it, cannot be confined to imposed institutional boundaries. Thus, the landscape encompasses landmarks that serve as aids to the collective memory and hence contribute to the cognitive or mental map that humans create out of landscapes (Byrne, 2010, p. 155; West \& Ndlovu, 2010, p. 218).

\section{Magagamatala-'green caves'}

The name is combined from magaga [caves] and matala [green], referring to the colour of the rocks at the caves in this mountain. As mentioned above, Magagamatala is historically associated with a Boer punitive expedition which attacked and defeated the Langa Ndebele there (Jackson, 1982, pp. 13-18).

Another incident associated with Magagamatala is the death of Mathe, an ancestor of Daniël Malope (the current ward headman of Moshuka, one of the interviewees) and his relatives Frans and Richard. A trap was set for a leopard by Johannes Monkwe, because the leopard had caught a donkey belonging to one of the people. However, the leopard managed to flee, with the trap still attached to its hind leg, and climbed onto a big rock. The pursuers wanted to turn back, but Mathe, who was with them, wanted to kill the leopard. The cornered animal leaped onto him and pulled the skin off his head. Mathe eventually died at home.

The mountain also has religious meaning: 'If you make a noise at Magagamatala, you will get lost. The badimo do not like it' (quote, Daniël Malope, April 2013). It is said that there is an image of the face of a white person on the rock face on the cliff outside the cave. Some people thought it was the face of God/Jesus because the image was too high-up for anybody to reach up and draw the picture. Abraham, one of the interviewees, reported seeing the image in 1947. The father of Rufus, another interviewee, also said he had seen it. The interviewees claimed that there are still leopards at Moshuka and at the cave at Magagamatala. 
Magagamatala was named for its physical features before any of the events described occurred, but it is best known for the attack by the Boer punitive expedition in 1858 , hence the discussion of this mountain under the topic of Mountains associated with historical events.

\section{Thabana ya kgoši - 'little mountain of the king'}

As its name indicates, and as explained above, this is the mountain where the Langa chief Mankopane resided, separate from his people, from 1854 until 1858, when his people at Magagamatala were attacked by a Boer punitive expedition. As mentioned, this precaution enabled Mankopane to escape. He fled to Thaba ya Kgoto (close to present-day Steilloopbrug on the N11 main road to Botswana - see Figure 1), before moving to Telekishi $(1 \mathrm{~km}$ south of the Masebe Nature Reserve) and back to Thutlwane (on the present-day farm Kromkloof 744LR, approximately $20 \mathrm{~km}$ south-south-east of the Reserve).

\section{Lebata}

This mountain reflects the history of the villages of GaMathekga and Dipêrê and contributes to the mental map of the landscape in which the Reserve is situated, despite the fact that Lebata lies outside the Reserve (cf. Byrne, 2010, p. 155; West \&Ndlovu, 2010, p. 218).

According to the interviewees, the name refers to something that is alone or a place that is deserted. There are two stories about where the name of this mountain originated. The first tells of the disappointment of the Mathekga - when they came from the Matlala, they were told that they would find the people of Tselapediat what is today known as GaMathekga at the bottom of the northern side of Lebata. When they arrived at GaMathekga (in 1944), they found that Tselapedi had already left for Dipêrê. So they called the mountain Lebata, indicating a place without people, only wild animals. (Mathekga was a Matlala chief when he was defeated by the BaTlokwa. He eventually settled at GaMathekga, and the Matlala then declared themselves subjects of the Langa Ndebele.) The second claims that the mountain is called Lebata because it stands alone, isolated fromtheothermountains.

Members of the zionist Christian Church used to fetch water from the top of the mountain, where there is a natural spring which is said to contain healing powers, although the spring is sometimes dry. Hence, the mountain has spiritual significance.

\section{Setlhakwame}

This is the 'place where the shoes (rampashanas) were tied' by the Langa warriors on their way to Morwadi (the'child of the Chief'). These warriors rode horses that they found at the hill at Dipêrê village.

\section{Morwadi - 'Daughter'}

During the reign of Chief Mankopane, who ruled the Langa from 1837 until 1877 (Jackson, 1982, pp. 6, 11-26), his daughter was killed on this mountain by a branch of the Birwa who, according to Van Warmelo (1953, pp. 23-26), resided to the north of the Masebe Nature Reserve, but to the south of Blouberg, the home of the Hananwa. This act enraged the Langa. To avenge her death, they left their goods at Diphikana (see above) and were treated by the ngaka so that the 
enemy would lose their way. Then, they went to Morwadi where Chief Mankopane's daughter was murdered-at that time, the mošate (capital [of the chief]) was already at Thutlwane Hill on the farm Kromkloof 744LR, south of Magagamatala (Jackson, 1982, p. 18). From Morwadi, the Langa warriors pursued the Birwa and found them at the small pool just southeast of Bojelaphiri and defeated them. (None of the sources in the literature consulted mention the killing of Chief Mankopane's daughter, or the battle between the Langa and Birwa in retaliation for the killing.)

According to one interviewee, a blind old man from Dipêrê, the families of Ramotebele, Bohlolo and Matlou once lived at Morwadi. The graves of their ancestors are still there, to the east at the bottom of the mountain. In 1952, these families moved to Dipêrê village, apparently because they felt too isolated. It has been a long time since the descendants have made sacrifices to the ancestors at Morwadi. There are a number of rock paintings at Morwadi, according to the interviewees. At the southern side of Morwadi, a man called Charles Daily also used to cultivate oranges.

These mountains clearly serve as tangible reminders of historical events that are not necessarily reflected in their names, but rather in the stories of the past associated with them (see Lengkeek, 2008, pp. 42-43). In this sense, these mountains can be seen as symbols of past events, whether because of incidents with animals, or skirmishes between people, or the movement and settlement of people. Taylor (2012, p. 27) usefully remarks that '(c)entral to these (places) has been the connection between present landscapes and the way in which they reflect vital links, tangible and intangible, with history', because they 'tell the story of people, events and places through time, offering a sense of continuity: a sense of the stream of time'(Taylor, 2012, p. 31).

\section{Mountains primarily associated with cultural practices}

The true significance of any landmark, such as a mountain, can only be attained when its underlying values and associated practices are revealed and understood (Munjeri, 2004, p. 18). However, such values and practices can only be retained by means of 'acts of remembering' and as 'the reiteration of group narratives of the past' (West \& Ndlovu, 2010, p. 218). The field of religion serves as an example with particular reference to Thaba ya badimo.

\section{Thaba ya badimo - 'mountain of the ancestors'}

The father of the village headman of Moshuka, Daniël Malope, was a diviner/bone-thrower (ngaka). He often went to Thaba ya badimo to get medicine (dihlare) and to talk to the ancestors (badimo). Furthermore, after the winter, all the dingaka, led by the old Malope, would go to this mountain to ask for rain. Sacrifices were also made to the ancestors (go phasa badimo) 'and the badimo would be asked to let their enemies just go away and leave them in peace' (quote, Ntona Daniël Malope and Ntona Mathekga, September 2012). Only the people of some of the villages surrounding the Masebe Nature Reserve go to this mountain to bring sacrifices. In particular, the villagers of Moshuka and GaMathekga regard this mountain as sacred and used it for the purposes of rain-making and bringing offerings to the ancestors. Since the residents of these two villages no longer have access to this mountain because of the fencing of the land, sacrifices to the ancestors on this mountain, as a form of 'acts of remembering' in respect of the significance of the mountain, can no longer be performed. In the long term, this exclusion could jeopardise the villagers' collective memory regarding the cultural landscape so that cultural values and 
practices attached to these places could become distorted and even extinct: 'Cultural landscapes are perceived to be particularly vulnerable to the impact of the loss of traditional human practices that reshaped them into the forms we value now' (West \& Ndlovu, 2010, p. 212).

Although in this article we argue that the way in which the people 'read'the landscape is not limited to or by institutional boundaries, it has to be noted that boundaries become an issue of concern when people are no longer allowed to visit places of particular cultural and historical significance, such as some of the mountains in the Masebe Nature Reserve. Meskell (2012, p. 19) remarked that by'fencing out people ... (c)onnections to historic or ancestral sites and ongoing traditions are attenuated and cultural and natural heritages remain oppositional'. Her comment is highly pertinent to what is happening at the Masebe Nature Reserve.

\section{Mountains where particular people lived}

Places can be regarded as human constructs endowed with meaning because people lived there (Byrne, 2010, p. 152; Schama, 1995, p. 10; Taylor, 2012). As we indicate below, there are places in the Masebe Nature Reserve to which meaning has been assigned by the local community because specific people occupied these places. Moreover, some of the same places where people once lived have also been assigned meaning because of the presence of entities other than humans. The research shows that landscape should indeed be valued for the relationship between human culture and the land, as it has been exploited by different communities (see West \& Ndlovu, 2010, p. 203), but it should also be valued for its association with supernatural and non-human beings. Interviewees might refer to a mountain such as Thaba ya badimo (see above), Mangwale or Thaba ya Mongatane, as lefelô la badimo [the place of the ancestors] or lefelô la Mamogašwa [the place of Mamogašwa]. However, it was found that the term for place, lefelô, is sometimes omitted, and instead of it, the locative suffix, $-n g$ (in the indigenous language, Sepedi), is applied to the noun to indicate place. This usually occurs when people are at the place/site-they will say: ke mo badimong-'it is here (the place) where the ancestors are'. This finding support the contention that 'people hold place to be the product of the lives of many living things, including extra-ordinary beings and non-human beings' (Harrison \& Rose, 2010, p. 258). At least three of the mountains, Mangwale, Thabana ya Ntebele and Thaba ya Mongatane, illustrate this statement (see also Moshuka, discussed above).

\section{Mangwale}

This mountain is just to the west of, but adjacent to, Magagamatala. The mountain was named after a clan, Mangwale, which stayed at the southern side of the mountain, at its foot. It seems that they left when the Langa entered the area. The two mountains form a neck where Mangwale and Magagamatala meet. At this neck, there is a fountain which is regarded as another dwelling place of Mamogašwa, the mythical water snake. The comments of the interviewees reveal that this fountain is shrouded in mystery: 'Sometimes when you go up this mountain and you get thirsty you won't find this fountain. At other times, when you are not thirsty, you will find it' (quote, Rufus Malisela, April 2013). At this neck between the two mountains, there is also a big cave on the eastern side as one goes up the mountain, and it is said that leopards used to give birth there.

There are also other pools at Masebe which are regarded as the dwelling places of Mamogašwa. Some interviewees were not sure whether these pools are the dwelling places of only one Mamogašwa, 
or whether there is more than one Mamogašwa, or whether the children of Mamogašwa live there. Others were of the opinion that Mamogašwa is not bound to one place, but can move from one water hole (dwelling place) to another, usually manifested in a whirlwind (Boonzaaier, 2010, p. 61; De Beer, 1999). In any event, it is said that these pools/springs should be avoided at midday as you will find or experience strange or extraordinary things-a hen with her chickens, blankets with bright colours belonging to nobody. One day some White people made a lot of noise at the bottom of Mangwale and got totally confused not knowing where they were. The next morning they were found by other Whites and taken away (quote, Rufus Malisela, April 2013).

\section{Thabana ya Ntebele - 'ittle mountain of Ntebele'}

This mountain was apparently named after a man with the name Ramotebele who lived at the foot of this mountain. He and his family moved to Dipêrê in the 1960s. The family graves are still at Thabana ya Ntebele, and the family's descendants still return there to make sacrifices.

\section{Thaba ya Mongatane - 'mountain of Mongatane'}

This mountain was apparently named after the first people who stayed at its foot. Today, some of the descendants of Mongatane still live in the villages of GaMonare and Dipêrê. This mountain is situated just inside the entrance to the eastern part of the Reserve. When enemies threatened the Langa, some of them escaped to the top of the mountain. However, some of the escapees died on top of the mountain and were buried there. These deceased are now ancestors (badimo) who are believed still to reside on this mountain. Hence, people should not climb this mountain, especially not at noon as it is the time when the badimo are at work-you can then hear them grinding grain. They may not be disturbed while at work' (quote, Ntona Daniël Malope, April 2013).

\section{Thaba ya Leburu - 'mountain of the boer'(white Afrikaner farmer)}

At some time in the nineteenth century, a white farmer stayed between this mountain and Thaba ya Mongatane, immediately to the west of it. The people can remember that he had an ox waggon and say that he left after the arrival of the Langa.

\section{Ngwanamang - 'whose child'}

The grave of a little girl who died on 15 January 1924, aged five years, is situated at the foot of this mountain. Her name and date of birth are engraved on the tombstone, without any other indication of who her family were. The local people also do not know what happened to her family-hence the name 'whose child (is this)'?

However, there are also other stories attached to this mountain, and particularly to the Motse river (Afrikaans: Klein Magalakwena; English: Little Magalakwena) that flows close by. In the past, when the Motse river (Klein Magalakwena) dried up, the river here did not dry up. In 1952, Mamphuryana, an unmarried man from Dipêrê, was found dead at this place and was buried there. Frans Sebata, one of the residents, found the body. At the western side at the foot of this mountain, there is an initiation (bodikana) place for boys. A heap of stones indicates the spot. 


\section{Mokgoba}

This mountain is at the entrance to the western part of the Reserve. It was named after Mokgoba Ramasobana, who lost control of the tractor he was driving and was killed in the road right next to this mountain. This mountain is also near a series of Bushmen rock paintings close to the western entrance to the Reserve. That is why, according to the interviewees, when people are at Makgoba mountain, they used to say: 'If you go to view the Bushmen rock paintings, you won't go far' (quote, Rufus Malesela, April 2013).

People once stayed at this mountain and it was even named after them, but like Mangwale, it is also a dwelling place of the mystical water snake, Mamogašwa. Both Thabana ya Ntebele and Thaba ya Mongatane were named after the people who once lived there. In both cases, these mountains are also the dwelling places of their ancestors to which taboo restrictions apply, and in the case of Thabana ya Ntebele, they return to bring sacrifices since this mountain is outside the Reserve.

No particular cultural significance is assigned to the remaining mountains, Thaba ya Leburu, Ngwanamang and Makgoba, except that they are associated with specific people who once lived there, or who are associated with the places because of a particular occurrence.

The fact that these mountains were named after people who once lived there can be interpreted as an indication of the relationship between people and the landscape that they live in. Particular associations, for instance, where particular mountains are seen as the dwelling places of the ancestors add further dimension to this relationship. Taylor rightly argues that these associations and intangible values 'symbolise "the acceptance and integration of communities and their relationship to the environment, even if such landscapes are linked to powerful religious, artistic or cultural associations of the natural elements rather than material cultural evidence" (UNESCO 2007a, p. 115, quoted in Taylor, 2012, p. 31).

\section{Conclusion}

In this article, we report on an exploration of the locally constructed meaning of mountains in the landscape of the Masebe Nature Reserve. Among other things, the empirical research supports the notion that landscapes mean different things to different people and that there are usually several 'versions' of a landscape or a landscape feature such as a mountain. It is not about 'truth', but about the local meaning(s) given to a landscape, so it is illuminating to investigate the layers of meaning attached to particular aspects and features of a landscape. At the same time, it is clear from this explorative research that landscapes are not a kind of coincidence, but that they are a materiality that speaks a 'language' (see Whiston Spirn, 1998), in a dialogue with the people living in that landscape. By giving meaning to and naming a landscape, people in a sense appropriate that landscape and make it their own. In the process, people start to fit into and become part of the landscape. It is a mutual process in which people derive meaning from their local landscape of belonging and attach meaning to it. In that sense, landscapes are as much about geography as they are about anthropology.

Juxtaposing this cultural reading with the inherently exclusionary character of the institutional arrangements that make up and demarcate the Masebe Nature Reserve with its fenced boundaries 
reveals social injustices vis-à-vis the local communities. It is the juxtaposition that brings social injustices to light. There is a hermetic logic to both discourses unto themselves, both in the cultural reading of the landscape and in the more clinical institutional logic of the Masebe Nature Reserve; in themselves, the two interpretive frameworks are difficult to counter. It is in their juxtaposition that the actual power differences between the two discourses come to light, a power difference that works to the detriment and exclusion of the local communities. In their own cultural reading of the landscape, the communities still consider themselves part of the landscape from which they are excluded by the institutional arrangements of the Masebe Nature Reserve.

Physical boundaries and cultural readings of landscape can diverge; a cultural reading of the landscape can transcend physical boundaries set by institutional arrangements. The risk is that physical exclusion results in a situation where local residents are denied access to 'their' cultural landscape inside the physical (fenced) boundaries of a reserve such as the Masebe Nature Reserve; the physical boundaries not only deny access-exclude-but also cut through the cultural reading and associated practices of the local residents, leading to considerable resentment among local residents towards reserves such as Masebe. These institutional practices often give nature conservation a bad name, even when it is linked to the noble-sounding packaged objectives of economic and developmental upliftment for (rather than with) local communities (see Andersson, De Garine-Wichatitsky, Cumming, Szingirai, \& Giller, 2012). By perceiving and planning economic development and institutional arrangements as a cultural process and programme, a start could be made to help eliminate some of the oppositional forces that are at play and experienced around the establishment of many (private) conservation areas around the world.

\section{Disclosure statement}

No potential conflict of interest was reported by the authors.

\section{ORCID}

Chris Boonzaaier http://orcid.org/o0oo-0002-8894-7295 


\section{References}

Andersson, J. A., De Garine-Wichatitsky, M., Cumming, D. H. M., Szingirai, V., \& Giller, G. E. (Eds.). (2012). Transfrontier conservation areas. People living on the edge. London: Routledge Earthscan.

Barnard, R. (2007). Apartheid and beyond. South African writers and the politics of place. Oxford: Oxford University Press. Boonzaaier, C. C. (2010). Rural people's perceptions of wildlife conservation-the case of the Masebe Nature Reserve in Limpopo Province, South Africa. Anthropology Southern Africa, 33, 55-64.

Boonzaaier, C. C., \& Wilson, G. D. H. (2011). Institutionalisation of community involvement: The case of Masebe Nature Reserve, South Africa. In R. van der Duim, D. Meyer, J. Saarinen, \& K. zellmer (Eds.), New alliances for tourism, conservation and development in eastern and southern Africa (pp. 165-184). Delft: Eburon.

Byrne, D. (2010). Heritage as social action. In G. Fairclough, R. Harrison, J. H. Jameson, \& J. Schofield (Eds.), The heritage reader (pp. 149-171). New York, NY: Routledge.

Cosgrove, D. E. (1984). Social formation and symbolic landscape. London: Croom Helm.

Cosgrove, D. E., \& Daniels, S. (Eds.). (1988). The iconography of landscape. Essays on symbolic representation, design and use of past environments. New York, NY: Cambridge University Press.

De Beer, F. C. (1986). Group solidarity in family law and the law of succession and inheritance among the Northern Ndebele (D. Phil. thesis). University of Pretoria, Pretoria.

De Beer, F. C. (1999). Mountains as cultural resources: Values and management issues. South African Journal of Ethnology, 22, 20-25.

Department of Rural Development and Land Reform (DRDLR). (2011a). 1:250 ooo Topo-cadastral map series (shapefiles). Mowbray, Cape Town.

Department of Rural Development and Land Reform (DRDLR). (2011b). 1:50 ooo Topo-cadastral map series (shapefiles). Mowbray, Cape Town.

Drori, G. S., Meyer, J. W., \& Hwang, H. (Eds.). (2006). Globalization and organizational change. Oxford: Oxford University Press.

Eckert, B., De Beer, F. C., \& Vorster, L. P. (2001). Worldviews and decision making: Natural resource management of the Laka of Mapela in an anthropological perspective. South African Journal of Ethnology, 24, 88-97.

Harrison, R., \& Rose, D. (2010). Intangible heritage. In T. Benton (Ed.), Understanding heritage and memory (pp. 238-275). Manchester, NH: Manchester University Press.

Jackson, A. O. (1982). The Ndebele of Langa. Ethnological Publications No. 54. Pretoria: Government Printer.

Lengkeek, J. (2008). The authenticity discourse of heritage. In D. Breeze \& S. Jilek (Eds.), Frontiers of the Roman empire. The European dimension of a world heritage site (pp. 37-53). Edinburgh: Historic Scotland.

Meskell, L. (2012). The nature of culture: The new South Africa. Oxford: Blackwell.

Munjeri, D. (2004). Tangible and intangible heritage: From difference to convergence. Museum International, 56, 12-20. Olwig, K., \& Mitchell, D. (Eds.). (2009). Justice, power and the political landscape. London: Routledge.

Ranger, T. (1997). Making zimbabwean landscapes: Painters, projectors and priests. Paideuma, 43, 5973. 
Ranger, T. (1999). Voices from the rocks: Nature, culture and history in the Matopos Hills of Zimbabwe. London: James Currey. Schama, S. (1995). Landscape and memory. London: Harper Collins.

Scheub, H. (2010). The uncoiling python. South African storytellers and resistance. Athens, OH: Ohio University Press. South African National Space Agency (SANSA). (2012). Satellite imagery. Pretoria: SANSA.

Taylor, K. (2012). Landscape and meaning: Context for a global discourse on cultural landscape values. In K. Taylor \& J. Lennon (Eds.), Managing cultural landscapes (pp. 21-44). London: Routledge.

University of Pretoria and Environmental Affairs. (2002). Environmental Potential Atlas (ENPAT). Pretoria: J. L. van Schaik Publishers.

Van Warmelo, N. J. (1953). Die Tlôkwa en Birwa van Noord Transvaal [The Tlôkwa and Birwa of the Northern Transvaal]. Pretoria: Government Printer.

Wels, H. (2000). Fighting over fences. Organisational co-operation and reciprocal exchange between the save valley conservancy and its neighbouring communities. Zimbabwe (Unpublished $\mathrm{PhD}$ thesis). Vrije Universiteit, Amsterdam.

Wels, H. (2003). Private wildlife conservation in Zimbabwe. Joint ventures and reciprocity. Leiden: Brill Academic.

West, S., \& Ndlovu, S. D. (2010). Heritage, landscape and memory. In T. Benton (Ed.), Understanding heritage and memory (pp. 238-275). Manchester, NH: Manchester University Press.

Whiston Spirn, A. (1998). The language of landscape. New Haven, CT: Yale University Press. 